\title{
A GRAFIA DOS CORPOS NO ESPAÇO URBANO: OS ESCOLARES NO ÁLBUM BIOGRAFIA DUMA CIDADE, PORTO ALEGRE, $1940^{1}$
}

DOI: http://dx.doi.org/10.1590/2236-3459/46286

\author{
Zita Rosane Possamai \\ Universidade Federal do Rio Grande do Sul, Brasil.
}

$\cos 80$

Resumo

Uma das formas de circulação das imagens fotográficas de temática educacional foi a edição dos álbuns comemorativos. No álbum Porto Alegre: biografia duma cidade, editado em 1940, a educação é mostrada pelas imagens de edificações e dos sujeitos fotografados. As complexas relações entre visível e invisível podem ser chaves para a compreensão dos modos a partir dos quais o poder constrói determinadas visualidades ligadas à educação. Nas imagens analisadas, a visibilidade é imperativo a partir do qual atesta-se a presença dos sujeitos, docilizados pela cultura escolar. A partir das imagens são construídos sentidos de ordem escolar e ordem urbana. A grafia da educação no espaço urbano se faz a partir do exercício do olhar do poder possibilitado pela grafia da luz - a fotografia.

Palavras-chave: Porto Alegre-RS, fotografia, cultura visual escolar, cultura fotográfica.

\section{THE BODY'S REGISTER IN THE URBAN SPACE: THE STUDENTS IN THE ALBUM BIOGRAPHY OF A CITY, PORTO ALEGRE, 1940}

\begin{abstract}
The edit of commemorative albums represented a way of circulation of photographs with educational thematic. In the album Porto Alegre: the biography of a city, issued in 1940, the education can be seen in the pictures of people and buildings. The complex relationship between the visible and the invisible can be important for the understanding of the ways the power uses to construct certain visual issues connected to education. In the analyzed pictures, the visual aspect is an imperative, as it makes it possible to see the subjects of study which have been educated and softened by the school's culture. School and urban issues are built from pictures. The education register in the urban space is made from what can be seen and this is possible thanks to the light register - the photography.

Key-words: Porto Alegre-RS, photography, school's visual culture, photographic culture.
\end{abstract}

\footnotetext{
${ }^{1} \mathrm{O}$ titulo é uma livre e poética associação à etimologia do termo fotografia, cujas raízes gregas (fóton, luz; grafia, desenho ou escrita) implica em concepção equívoca do processo fotográfico, conforme as considerações de Frizot (2012).

ก. 47

Set./dez., 2015 p. $129-148$
} 


\section{EL REGISTRO DE LOS CUERPOS EN EL ESPACIO URBANO: LOS ESCOLARES EN EL ÁLBUM BIOGRAFÍA DE UNA CIUDAD, PORTO ALEGRE, 1940}

\section{Resumen}

Una de las formas de circulación de imágenes fotográficas de temática educacional fue la edición de álbumes conmemorativos. En el álbum Porto Alegre: biografía de una ciudad, editado en 1940, la educación está presente a través de las imágenes de las edificaciones y de los sujetos fotografiados. Las complejas relaciones entre lo visible y lo invisible pueden ser consideradas clave para la comprensión de las formas, a partir de las cuales, el poder construye determinadas visualidades ligadas a la educación. En las imágenes analizadas, la visibilidad es un imperativo a partir del cual se ven los sujetos escolarizados y suavizados por la cultura escolar. A partir de las imágenes, se construyen los sentidos de orden escolar y urbana. El registro de la educación en el espacio urbano se realiza a partir de lo que se puede ver y esto es gracias al registro de la luz - la fotografía.

Palabras-clave: Porto Alegre-RS, fotografía, cultura visual escolar, cultura fotográfica.

\section{LE GRAHPIE DES CORPS DANS L'ESPACE URBAINE: LES ÉCOLIERS DANS L'ALBUM PHOTOGRAPHIQUE BIOGRAFIA DUMA CIDADE, PORTO ALEGRE, 1940}

\section{Resumé}

L'article analise les images photographiques sur l'education dans l'álbum Porto Alegre: biografia duma cidade, edité en 1940, à Porto Alegre-RS, Brésil. Dans ces imagens sont presentées lês batiments scolaires et lês sujets de l'école. Les relations entre le visible et l'invisible sont proposés pour comprendre les divers moyens de création des visualités pour le pouvoir. Dans ces images les scolaires sont presentées dans une ordre scolaire et urbaine, possibilité par la photographie. Mots-clé: Porto Alegre-RS, photographie, culture visuel scolaire, culture photographique. 
$\mathrm{P}$ ara os limites desse artigo, recorro a duas particularidades do fotográfico, apontadas por Michel Frizot (2012), como ponto de partida para análise da fotografia circunscrita ao contexto educacional brasileiro: a produção de imagens fotográficas e o método de comunicação derivado da reprodutibilidade ilimitada. No primeiro caso, por um lado, trata-se de da criação de imagens que se caracterizam pela observação a partir de um ponto de vista conformado por um engenho técnico, a câmera fotográfica, que, por sua vez, obedece aos parâmetros da perspectiva renascentista de representação da realidade (Dubois, 1992; Machado, 1984; Flusser, 2002); por outro lado, trata-se de imagens criadas em homologia ao seu referente, que remetem ao real, criando a ilusão de refletir esse real tal qual um espelho.

Essa última acepção da fotografia, desde a sua expansão no século 19 , gerou sua utilização pragmática no sentido de documentar mundos distantes percorridos pelas expedições fotográficas ou as transformações próximas, advindas das reformas urbanas modernizadoras das principais cidades européias e brasileiras (Mondenard, 1999; Ferrez et al, 1982). No Brasil, no escopo educacional, documentar foi uma das principais funções atribuídas à fotografia, seja pela produção de imagens da edificação escolar, das turmas de escolares ou dos professores (Barros, 1994; Souza, 2001; Bencosta, 2011; Vidal; Abdala, 2005). Nesse sentido, o Estado, mantenedor da escola, constituiu-se como a principal agência produtora de imagens fotográficas, muitas vezes destinadas à publicação e à circulação no interior dos relatórios oficiais. Nesse caso específico, as imagens fotográficas tiveram, muitas vezes, o objetivo de mostrar as obras realizadas ou em andamento, sendo as edificações escolares o principal objeto fotografado. Os prédios escolares atestavam a presença da educação no espaço urbano, assim como sua imagem visual apresentava a educação num determinado imaginário urbano construído como imagem visual (Bencostta, 2004; Faria Filho, 2000).

Nas primeiras décadas do século 20, no Rio Grande do Sul, em especial na capital Porto Alegre, as imagens fotográficas também foram utilizadas pelo poder público, tanto municipal, quanto estadual, com a finalidade de documentar as obras realizadas, neste caso, as construções de edificações escolares. São imagens que valorizam exclusivamente o objeto arquitetônico, quase sempre descontextualizado do espaço urbano. A presença das edificações escolares nessas imagens fotográficas atesta a importância da construção de uma visualidade que mostra a educação na cidade. A imagem fotográfica de edificações monumentais em estilo eclético pretendia mostrar o grau civilizatório alcançado pela sociedade republicana sul-rio-grandense e o lugar da educação nesse contexto, em nítido contraste com a precária situação da maioria das escolas do Estado (Possamai, 2009).

Em estudo anterior ${ }^{2}$ demonstrou-se que a construção de novas edificações, em sintonia com os preceitos requeridos por uma modernidade pedagógica, não acompanhava na mesma velocidade o surgimento de escolas, que eram abrigadas em salas alugadas e com inadequadas condições higiênicas. Nesse sentido, a produção de imagens fotográficas das novas edificações se, por um lado, teve o sentido de

\footnotetext{
${ }^{2}$ Para análise apresentada em Possamai (2009) foram consultados os relatórios da Secretaria de Obras Públicas do Estado do Rio Grande do Sul, entre os anos de 1899 e 1927.

n. 47

Set./dez., 2015

p. $129-148$
} 
documentar uma realidade homóloga à imagem, por outro lado, criara sentidos visuais vinculados a um ideal de escola almejada cuja arquitetura dos novos edifícios poderia materializar-se também por meio da imagem.

Dessa forma, é possível verificar os matizes da cultura fotográfica passando a permear a vida social, nesse caso específico também perpassando a cultura escolar (Felgueiras, 2005; Julia, 2001; Viñao, 2010). É importante, no entanto, relativizar esse diálogo entre cultura fotográfica e cultura escolar, no caso da produção das fotografias de obras construtivas. A partir do proposto por Meneses (2005) como visual - compreendido pelos sistemas visuais da sociedade e as instituições que os produzem - aqui interessa abordar as instituições educacionais, especialmente a escola, como produtora, conformadora e agenciadora de visualidades instituídas por uma cultura escolar que se configura, sobretudo, no espaço escolar, desde o desenho arquitetônico dos edifícios, passando pela visualidade impingida aos estudantes nos modos de vestir-se, portando uniformes, e de locomover-se em filas, até a disposição da cultura material (mobiliários, artefatos pedagógicos, livros e cadernos) em sala de aula.

Essa visualidade particular configura uma determinada cultura visual escolar, inserida na cultura visual (Knauss, 2006; Hernandez, 2000) mais ampla e circunscrita à cultura da escola e intimamente imbricada com a cultura material produzida por essa, uma vez que a imagem visual não se dissocia dos suportes pelos quais circula, seja na escola, seja para fora desta, adentrando os lares dos sujeitos envolvidos ou configurando veículos de divulgação e documentação, tais como os relatórios oficiais acima mencionados.

No contexto estudado a escola pública ainda não se constituía em produtora de imagens fotográficas, como será em períodos posteriores a partir da massificação da fotografia, embora a visualidade escolar seja compartilhada pela cultura fotográfica que transformava em imagem não apenas as edificações escolares, mas também os sujeitos. No contexto em análise, os órgãos oficiais, Governo do Estado e Prefeitura de Porto Alegre, constituíram-se em instituições produtoras de imagens fotográficas por excelência, contratando fotógrafos e fazendo uso das imagens para ilustrar seus relatórios e, esporadicamente, fazendo circular essas imagens por meio de álbuns fotográficos.

Desse modo, as imagens fotográficas inseridas nos relatórios oficiais constituem-se em pistas à História da Educação no sentido não de construir uma história por meio das imagens, mas por contemplarem a dimensão visual do social, nesse caso, da educação. Assim, fotografar a nova edificação escolar e criar uma imagem visual da escola configuram-se práticas concernentes a uma cultura fotográfica, moldada por um imaginário também fotográfico:

Por imaginário, consideraremos aqui tudo o que se constitui mentalmente em torno de uma prática, de uma cultura técnica, e que comporta essas características: o que se liga a conceitos armazenados, o que se prende à memória através de noções que pertencem propriamente à fotografia. (Frizot, 2012, p. 37)

A produção das imagens de edificações publicadas nos relatórios oficiais pode ser de interesse para a análise histórica, tendo, no entanto, a característica de circulação restrita na sociedade, ao contrário de suportes como cartões postais, álbuns fotográficos, 
vistas urbanas avulsas, revistas ilustradas. Esses suportes estiveram presentes em diversos contextos urbanos brasileiros, a partir da segunda metade do século 19 e apontam para uma produção de imagens fotográficas voltada ao consumo mais amplo das populações.

A peculiaridade de múltipla reprodutibilidade das imagens fotográficas constitui-se, segundo Michel Frizot (2012), como um dos elementos a considerar para o surgimento de uma cultura fotográfica que passa a penetrar no tecido social e cujo número exponencial de imagens contribui de modo inexorável, além dos produtores amadores e profissionais, da comercialização de uma gama diversificada de aparatos tecnológicos para realizar imagens, entre outros aspectos.

As facilidades de produção e circulação das imagens na era da internet deixam esmaecido no tempo o grande salto que significou para a fotografia ultrapassar seu primeiro artefato configurado nos daguerreótipos - uma imagem sobre uma placa de metal, acessível a poucos -, para o carte de visite, impressão em papel que permitiu a ampla comercialização de imagens. Desse modo, da câmera escura ao daguerreótipo e deste aos processos de impressão fotomecânica, que permitiram a impressão de imagens fotográficas em milhares de exemplares - jornais, revistas, álbuns, cartões postais -, a fotografia só fez aumentar seu público consumidor. Dos cartões postais chegou-se rapidamente aos álbuns fotográficos, suportes interessantes para análise das imagens de temática educativa. Editados com os mais variados objetivos e tendo características também bastante diversas, os álbuns constituíram-se em veículos de representações criadas sobre determinada temática ou objeto. Os álbuns fotográficos estiveram presentes em momentos comemorativos em diferentes contextos brasileiros, sendo um dos objetos produzidos ao lado de festividades, paradas militares, exposições.

Neste texto analisarei o álbum Porto Alegre: biografia duma cidade (Franco, s.d.), editado na capital do Rio Grande do Sul, no ano de 1940, detendo-me nas imagens fotográficas que este comporta sobre a temática da educação. Mas antes de abordar os aspectos simbólicos concernentes às imagens presentes nesse álbum, convém uma aproximação deste como artefato, pois do mesmo modo que a fotografia depende de um suporte, daí sua configuração material, os álbuns constituem-se em objetos com características de produção, circulação e consumo que the dão peculiaridades muitas vezes distintas das imagens fotográficas por eles comportadas. A edição foi concebida por Léo Jerônimo Schidrowitz, tendo ainda como organizadores o capitão Álvaro Franco e o major professor Morency de Couto e Silva. Foi apresentada como proposta editorial à Prefeitura da capital, que preparava os festejos do seu bicentenário. Muitas das imagens fotográficas inseridas no álbum eram provenientes de três coleções - fotógrafos Barbeitos \& Irmãos, Irmãos Ferrari e Virgilio Calegari - consideradas as mais antigas da cidade e adquiridas pela municipalidade no contexto da organização dos festejos (Possamai, 2001). Publicado sob patrocínio da Prefeitura e com a colaboração de outras instituições, o álbum foi oficializado como livro comemorativo dos duzentos anos da cidade de Porto Alegre.

Porto Alegre: biografia duma cidade é composto por 664 páginas, em tamanho $27 \mathrm{~cm}$ $x 37 \mathrm{~cm}$, com capa dura, nas cores amarelo e verde. A escolha dessas cores remete à nacionalidade, uma vez que seus organizadores tinham a pretensão que esta edição fosse uma das monografias da série Brasília Aeterna, cujo objetivo era mostrar as cidades 
brasileiras de importância histórica. A edição fora limitada, sendo o nome do seu recebedor registrado numa das folhas de rosto da obra. Nas primeiras páginas de Biografia estão ainda presentes os retratos das principais autoridades do período (presidente, interventor do Estado do Rio Grande do Sul, prefeito, arcebispo e comandante da $3^{a}$ Região Militar). A obra compõe-se de três partes antecedidas por um sumário que enuncia os textos, escritos por especialistas. Inicia por Parte geral, que abrange dados geográficos - clima, fauna, flora, demografia -, urbanísticos e econômicos. A segunda parte, intitulada Passado fornece informações sobre a história da capital, a evolução arquitetônica, história política, figuras destacadas, cultura e desenvolvimento. Finalmente, a terceira parte, denominada Presente e futuro, é composta por informações sobre aspectos político-administrativos e religiosos, educação, vida cultural e literária artes, teatro, museu, música, arquitetura -, economia, turismo, vida social, cidade do futuro.

Além do texto escrito são apresentados mapas e gráficos estatísticos sobre assuntos diversos: veículos, bondes, iluminação pública e particular, assistência médicosanitária, melhoramentos, tráfego aéreo, movimento portuário, extensão das linhas telefônicas. Fazem parte da edição imagens de obras artísticas impressas em papel cartonado. São gravuras, pinturas a óleo, aquarelas de artistas proeminentes no período, como Ângelo Guido, José Lutzenberger, Nelson Boeira, Luis Mauristany Trias, entre outros. Algumas imagens fotográficas também estão apresentadas nessa conformação, trazendo a indicação precisa de seus autores, como Virgilio Calegari e Studio Os 2, fato que não ocorre com as demais fotografias da publicação.

A edição é referida como livro e nas suas páginas o texto escrito sobrepõe-se às imagens, principalmente na divisão de espaço concedido a ambas as linguagens. As imagens ocupam, geralmente, um terço de cada página, enquanto o texto ocupa dois terços do espaço. Quase sempre as imagens estão acompanhadas dos textos sobre o assunto, sendo a imagem fotográfica utilizada como ilustração das informações fornecidas pelo texto. Outra forma de apresentação das imagens fotográficas abrangem as seções Reminiscências gráficas, Excursão caleidoscópia da cidade e Álbum da sociedade metropolitana. Estas seções são compostas, exclusivamente, por imagens fotográficas legendadas. A primeira compreende retratos de jovens, cenas de caça, veículos, baile popular, clube de ciclistas, entre outras. A segunda representa os espaços urbanos, como ruas, praças e edificações e a terceira apresenta retratos de personalidades femininas da sociedade porto-alegrense, de famílias e de crianças.

As imagens fotográficas caracterizam-se por tomadas parciais e pontuais, que possibilitam a representação de amplos espaços da urbe. Edificações, jardins, praças e áreas verdes; ruas, esquinas e avenidas; o lago Guaíba estão entre os motivos mais recorrentes na publicação. Alguns temas são apresentados em diferentes tomadas, como Docas, que totalizam seis imagens sobre o mesmo referente. Ainda estão presentes várias vistas aéreas do centro da cidade, permitindo uma visão ampla do promontório.

Charles Monteiro (2008) problematizou a utilização das imagens fotográficas em Porto Alegre: biografia duma cidade analisando, especificamente, duas das séries fotográficas ali apresentadas. Nas palavras do autor, 
a tríade passado, tradição e modernidade caracteriza uma equação discursiva e visual na obra, que faz as glórias conquistadas no passado se prolongarem nas realizações do presente, visando à constituição de uma sociedade moderna, ordenada, higiênica e produtiva, que se projeta para o futuro. (Monteiro, 2008, p. 165)

O tom discursivo da obra, nesse sentido, tenta mostrar por imagens, textos e gráficos estatísticos uma cidade em grande crescimento populacional e econômico. Os dados apresentados almejam construir a imagem de uma cidade em transformação, graças às intervenções modernizadoras do espaço urbano. As modificações levadas a efeito no presente são ainda, reforçadas pelo expediente de utilização de imagens fotográficas do passado, que permitem o diálogo entre a cidade que um dia foi e a cidade do presente.

O viés laudatório e ufanista em relação aos feitos realizados pelos executivos estadual e municipal insere-se na tradição dos álbuns fotográficos editados pelo poder público no Estado. No caso específico de Porto Alegre: biografia duma cidade cumpre, ainda, inserir sua produção no contexto político do Estado Novo (1937-1945), cuja centralização política era especialmente marcada no contexto regional pela intervenção federal. A política educacional do Estado Novo tinha por objetivo a construção de um projeto de educação nacional, levada a cabo no Rio Grande do Sul pelo interventor Cordeiro de Farias e pelo secretário J. P. Coelho de Souza (Bastos, 2005), personalidade política rodeada por elogioso discurso nas páginas da publicação. Conforme Maria Helena Camara Bastos,

a busca da homogeneização nacional através de um projeto de nacionalização envolvia, segundo Schwartzzman (1984, p. 149-152), três aspectos: dar conteúdo nacional à educação transmitida pelas escolas e por outros instrumentos formativos; padronizar o sistema escolar e educacional na perspectiva da homogeneização e centralização e erradicar as minorias étnicas, lingüísticas (sic) e culturais. (Bastos, 2005, p. 51)

No Rio Grande do Sul a campanha de nacionalização do ensino atingiu diretamente as escolas étnicas mantidas nas regiões de colonização alemã e italiana desde o século 19 (Kreutz, 1994). Conforme René Gertz (2005), a nacionalização ensejou uma série de práticas violentas, desde o fechamento e a vigilância ostensiva das escolas, a fim de assegurar o ensino do idioma nacional, até perseguições. Ademais, o sentimento de brasilidade era estimulado pela prática de comemorações cívicas ligada às efemérides e aos grandes vultos do passado. O contexto de produção da obra Porto Alegre: biografia duma cidade e sua íntima relação com os poderes políticos estabelecidos naquele momento histórico apontam para uma visualidade criada, tendo como balizas os princípios propugnados pelo Estado Novo, especialmente no que se refere à educação.

\section{A educação no espaço urbano}

Entre as imagens publicadas no álbum Porto Alegre: biografia duma cidade, 33 foram selecionadas por terem relação com a temática educacional. A estas imagens foi aplicada uma grade interpretativa, cujas categorias permitiram observar as características do conjunto. Uma destas categorias faz referência à tipologia do objeto fotografado, 
diferenciando-o entre edificação, atividade e retrato. Assim, 18 imagens apresentam o motivo principal focado em edificações educativas: escolas, universidades, faculdades, institutos; nove imagens referem-se a atividades: eventos, paradas e desfiles; seis imagens são retratos individuais de autoridades ou de pequenos grupos composto por menos que dez indivíduos.

As imagens de edificações podem ser sub-divididas entre aquelas cujo referente são os prédios das faculdades (8) e aquelas cujo referente são escolas e ginásios (10). Este segundo sub-conjunto apresenta em sua maioria imagens de escolas privadas da cidade, cujas mantenedoras são congregações religiosas. Caracterizam-se por vistas parciais, muitas em diagonal e que contextualizam o edifício no espaço urbano. As imagens das faculdades apresentam a fachada principal do edifício, isolando-o do contexto urbano e enaltecendo suas formas arquitetônicas.

É digno de nota que imagens de edificações escolares construídas na capital pelo governo do Estado, nas décadas anteriores à publicação do álbum, não estejam presentes, com exceção da imagem da edificação do Instituto de Educação (fotografia 1), responsável pelo ensino normal e secundário, conforme informa legenda da imagem. A imagem da edificação do Instituto de Educação merece especial consideração, pois esta dá visibilidade à transformação da escola normal de Porto Alegre em Instituto de Educação, alterando sua estrutura e organização em 1939. Conforme Maria Helena Camara Bastos (2005), a formação de professores constituía-se em uma das estratégias na formação do homem novo e da renovação educacional levada a efeito no Estado Novo que, nessa perspectiva, implementou uma política de valorização do docente em atividade como o mestre do futuro, embora critérios elitistas e o atendimento às prerrogativas da nacionalização fossem privilegiados no âmbito do Plano de Carreira do Magistério instituído. A formação dos professores no novo espírito educacional envolvia a divulgação de obras sobre a Escola Nova de autores como Lourenço Filho, bem como o estímulo aos estudos sobre os conteúdos pedagógicos, proibindo-se discussões que não versassem sobre os problemas profissionais (Bastos, 2005).

A Escola Normal de Porto Alegre, transformada em Instituto de Educação, passou a ser um pólo de difusão das novas tendências educacionais, daí a sua presença em Biografia ganhar eloqüência pela sua configuração arquitetônica. Desse modo, a visibilidade da edificação do Instituto pode ser interpretada aqui de modo a dar visibilidade a uma política de formação dos professores no novo projeto educacional em implantação no Estado do Rio Grande do Sul, cuja participação dos professores era de vital importância. Desse modo, na trama entre visibilidade e invisibilidade o desejo dos editores do álbum direcionava-se para evidenciar uma política de governo, evidenciada nas narrativas textuais que enumeravam seus feitos na área da educação e não, necessariamente, os sujeitos docentes do Instituto, muitos dos quais formados ainda nas concepções tradicionais anteriores ao escolanovismo (Bastos, 2005). 
Fotografia 1 -

O Instituto de Educação, o magnífico estabelecimento de ensino normal e secundário (legenda original).

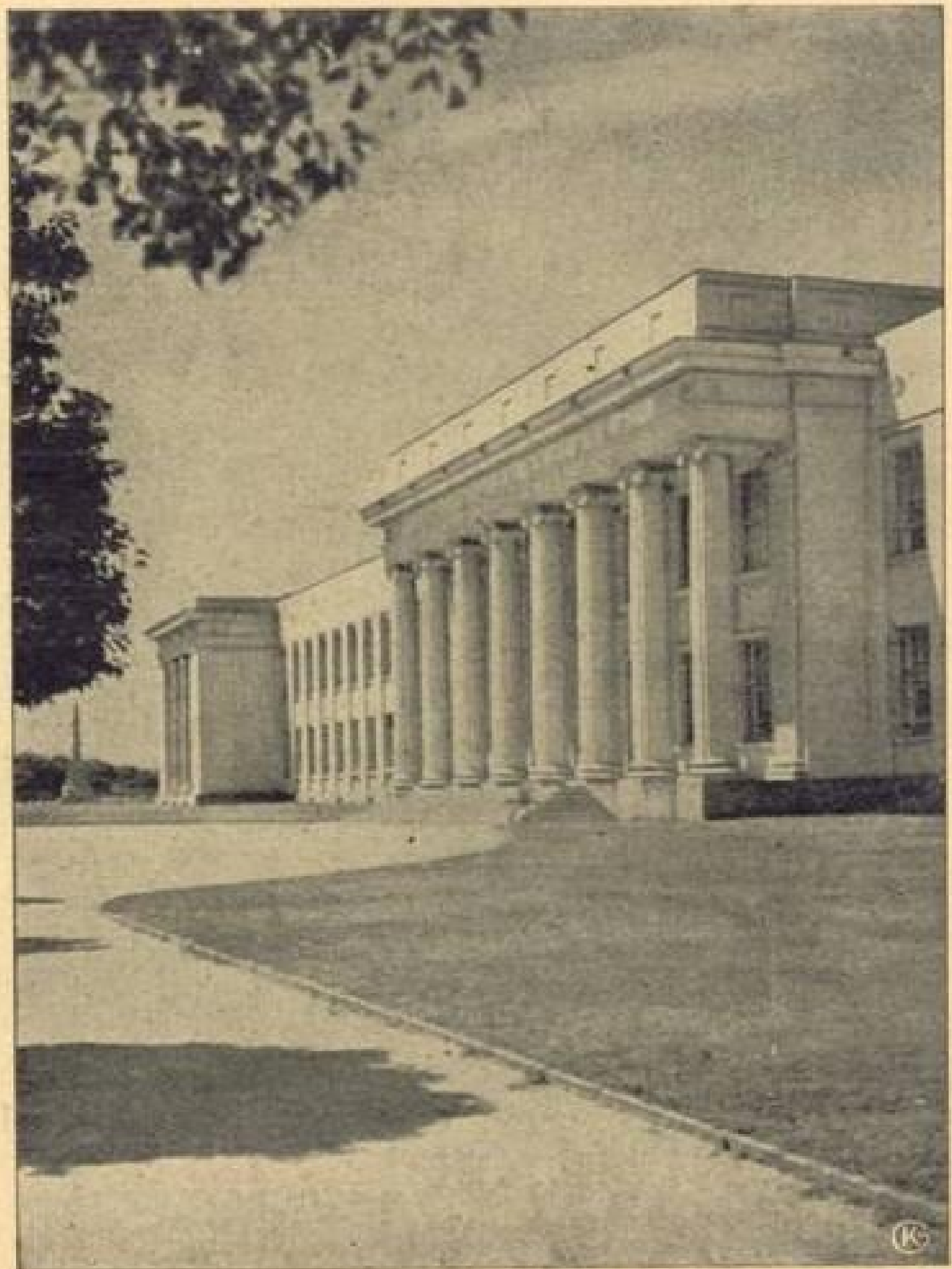

\section{O Instituto de Educação, o magnífico estabelecimento de ensino normal e secundário}

Fonte: Franco, A. et al. Porto Alegre: biografia duma cidade. Monumento do passado, documento do presente, guia do futuro. Porto Alegre: Tipografia do Centro, s.d. 
As edificações escolares como principal objeto que atesta a presença da educação na imagem fotográfica foi observada em outros documentos consultados (Possamai, 2009). Nas primeiras décadas do século 20, em Porto Alegre, a carência de escolas e a precariedade de suas instalações tornaram urgente a construção de edificações escolares que seguissem os padrões exigidos pela modernidade pedagógica. Neste caso, a preocupação maior da obra construtiva calcava-se sobre o ensino elementar. As imagens fotográficas estudadas, nos anos 1920, apresentavam exclusivamente a edificação e, raras vezes, os sujeitos envolvidos com a escola. A ausência de imagens das escolas públicas da capital pode ser compreendida mais uma vez recorrendo-se ao contexto educacional do período, no qual pode ser observado grandes investimentos na construção de prédios escolares no meio rural. O programa de construção de edificações escolares nos municípios tinha um duplo objetivo: alcançar as zonas de imigração italiana e alemã, principal alvo da nacionalização do ensino, e conter a população no campo, evitando os movimentos de êxodo rural e mantendo a ordem nas cidades ${ }^{3}$.

Em Biografia a ênfase da educação vinculada ao Estado recai no ensino superior, pelas imagens fotográficas das edificações das Faculdades de Direito, de Engenharia, de Ciências Econômicas e de Medicina (fotografia 2). Desta última instituição são apresentadas cinco imagens: uma imagem da fachada principal, uma da fachada lateral $e$ três imagens internas dos laboratórios e das salas de aula. A recorrência do motivo fotografado demonstra a importância de tal instituição educacional no contexto estudado, assim como a recorrência de imagens das edificações e espaços internos das faculdades dá visibilidade ao papel do governo do Estado na criação da Universidade Porto Alegre, num momento de acalorados debates na seara educacional entre três grupos: positivistas herdeiros do castilhismo, reunidos em torno da Escola de Engenharia e Faculdade de Direito; católicos; adeptos da Escola Nova, reunidos no Partido Universitário (Bastos, 2005). A criação da UPA selou o rompimento do governo com a ortodoxia positivista que pregava o ensino livre, sendo contrário à intervenção oficial no ensino universitário.

Em Porto Alegre: biografia duma cidade as imagens das edificações das faculdades apresentam-se com alta valorização, pelas tomadas da fachada principal ou tomadas em diagonal que ressaltam a volumetria da edificação. Estas edificações não são mostradas isoladas nas imagens, mas são vistas que inserem a edificação no espaço urbano ao lado de outros elementos, como o automóvel, as avenidas e as praças, criando um cenário visual em conformidade com os padrões de uma cidade moderna, notadamente a capital do Estado do Rio Grande do Sul, em sintonia com a posição alçada pelo ensino superior no contexto não apenas urbano, mas social. Ao mesmo tempo em que valoriza visualmente o ensino superior na capital, o álbum constrói sentidos de divisão regional da educação no território do Estado, uma vez que põe em evidência o ensino secundário e normal, além do ensino universitário, localizados na capital.

\footnotetext{
${ }^{3}$ Bastos (2005) menciona que já se evidenciava o êxodo rural no período, embora os moradores do campo constituíssem $69 \%$ da população total do Estado. Ainda conforme a autora, manter a população no campo, por outro lado, era imprescindível para a manutenção da posição do Rio Grande do Sul na economia nacional como celeiro do País. 
Fotografia 2 -

Faculdade de Medicina (legenda original).

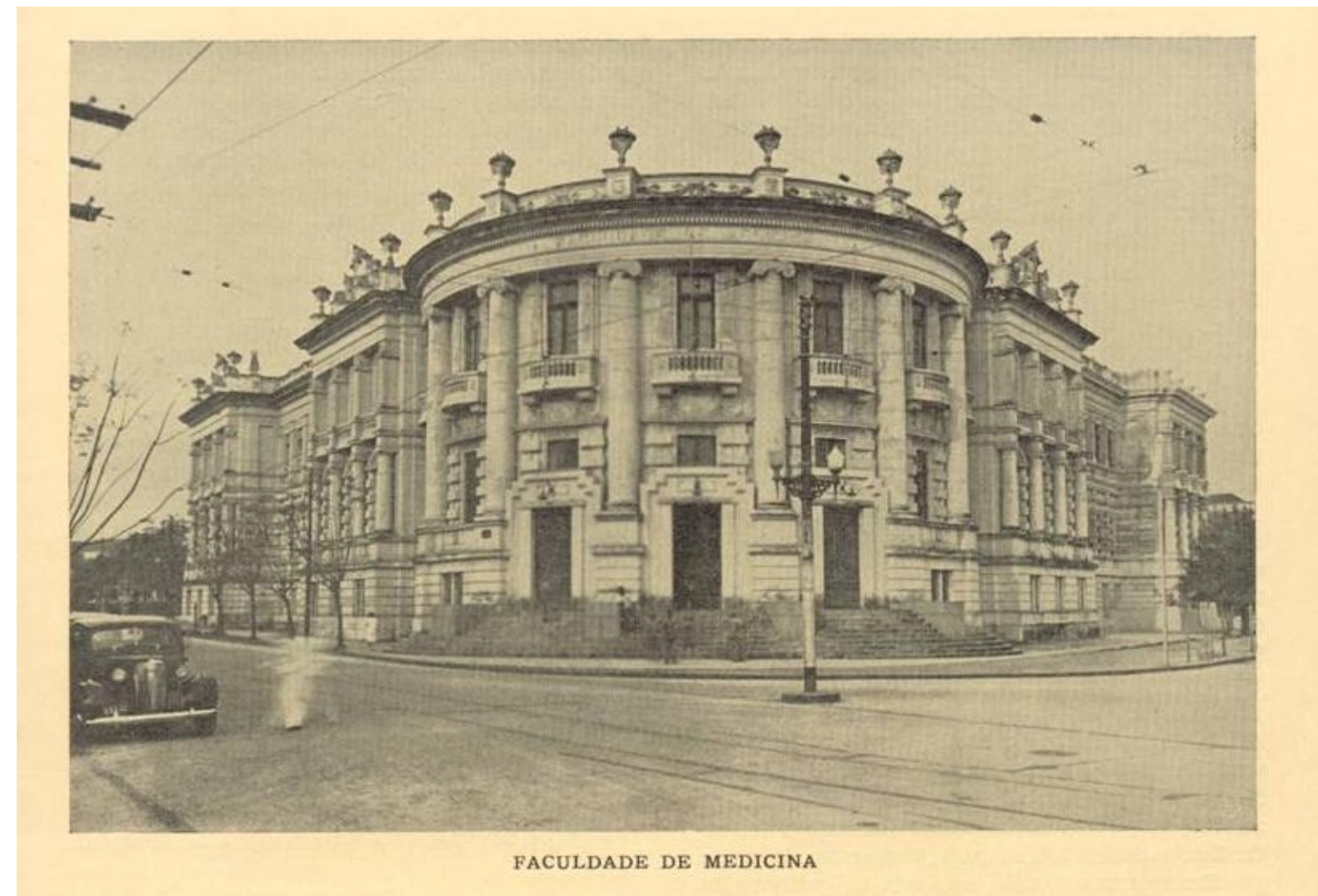

Fonte: Franco, A. et al. Porto Alegre: biografia duma cidade. Monumento do passado, documento do presente, guia do futuro. Porto Alegre: Tipografia do Centro, s.d.

Característica diferenciadora das imagens relacionadas à temática educativa em Biografia está na presença dos sujeitos fotografados. Praticamente ausente em imagens fotográficas de períodos anteriores, neste álbum são recorrentes os retratos e as imagens de grupos de escolares. Os retratos - considerados como imagens individuais ou em grupo especialmente produzidos com o consentimento do fotografado que posa compreendem autoridades e corpo docente e discente. Embora no conjunto total de imagens analisadas prepondere a ausência de sujeitos (14) - característica das tomadas de edificações -, o maior número de imagens que apresenta sujeitos, totalizando 15 imagens nas categorias atividade e retrato, recai na categoria multidão, considerada aqui como imagens apresentando um número maior que 10 pessoas, sendo as demais imagens individuais ou de pequeno grupo, menos que dez pessoas.

Em três dessas imagens a edificação educativa é mostrada em segundo plano do corpo de oficiais, alunos e docentes da Escola de Cadetes, compondo um cenário no qual os sujeitos estão inseridos num quadro maior. A recorrência da presença dos sujeitos envolvidos com a antiga Escola de Guerra encontra explicação no contexto estudado, assim como as imagens das atividades, como desfiles e paradas organizadas nas avenidas de Porto Alegre ou atividades culturais e esportivas, identificadas na categoria multidão. Desse modo, a presença dos escolares é vista nas imagens dos desfiles e paradas que guardam a característica de festa em continuidade com o cotidiano 
escolar, em que a escola como unidade apresenta-se à sociedade, sendo-lhe reservado papel preponderante na inculcação de valores cívicos, em conformidade com o contexto analisado (Bencosta, 2011).

Nestas imagens os sujeitos fotografados são, em sua maioria, alunos das escolas da cidade, apresentados uniformizados, organizados em fileiras, preparando-se para a parada ou desfilando. Essas imagens criam sentidos de ordem, igualando os sujeitos fotografados, apresentados como um corpo homogêneo e uniforme. O sentido de homogeneidade é construído a partir das tomadas dos alunos uniformizados (fotografias 3 e 4).

Fotografia 3 -

Desfile de alunos por ocasião da Parada da Juventude (legenda original).

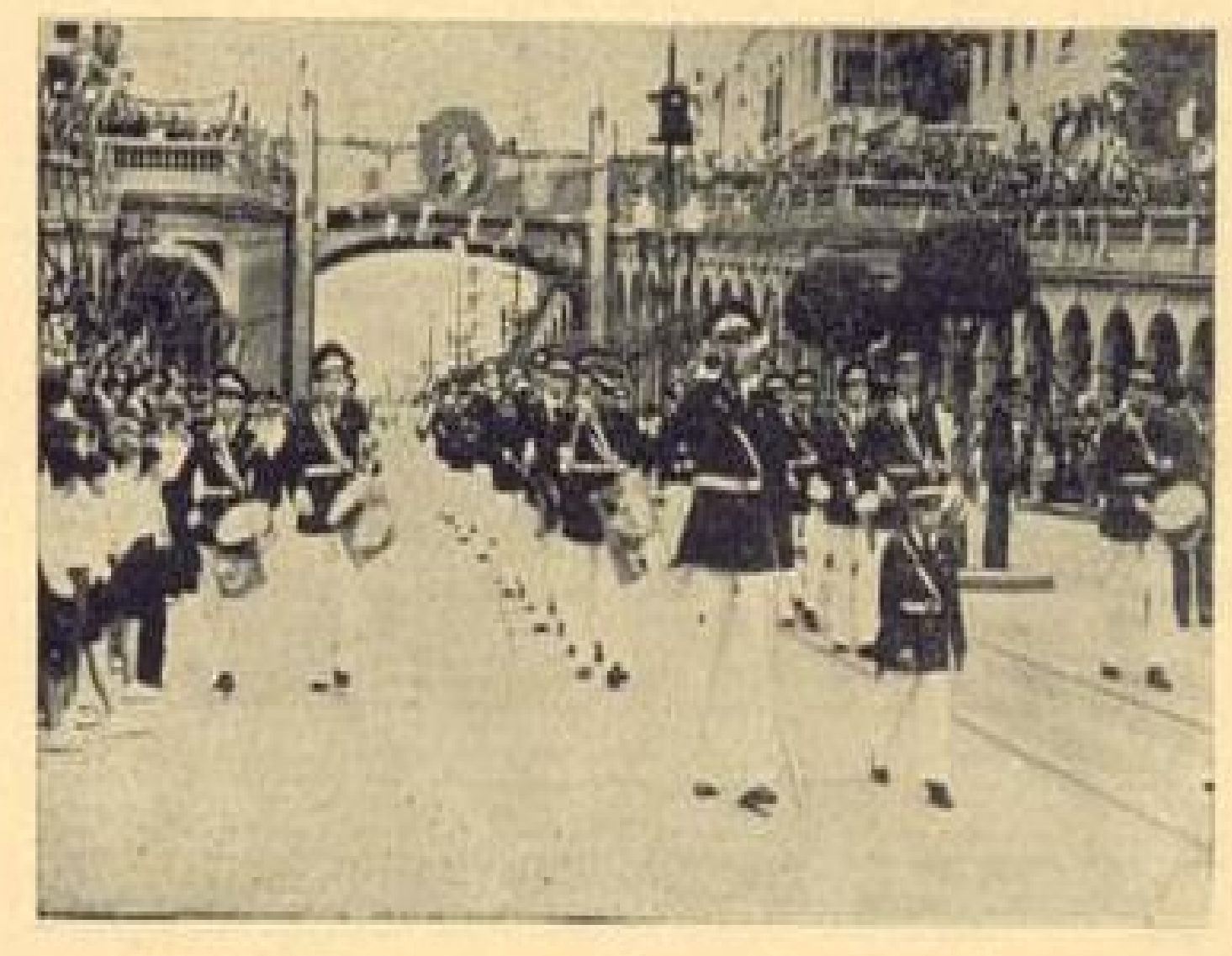

\section{Desfile de alunos por ocasiâo da Parada da Juventude}

Fonte: Franco, A. et al. Porto Alegre: biografia duma cidade. Monumento do passado, documento do presente, guia do futuro. Porto Alegre: Tipografia do Centro, s.d. 
Fotografia 4 -

Corpo de alunos do Ginásio Bom conselho, em dia de desfile pátrio (legenda original).

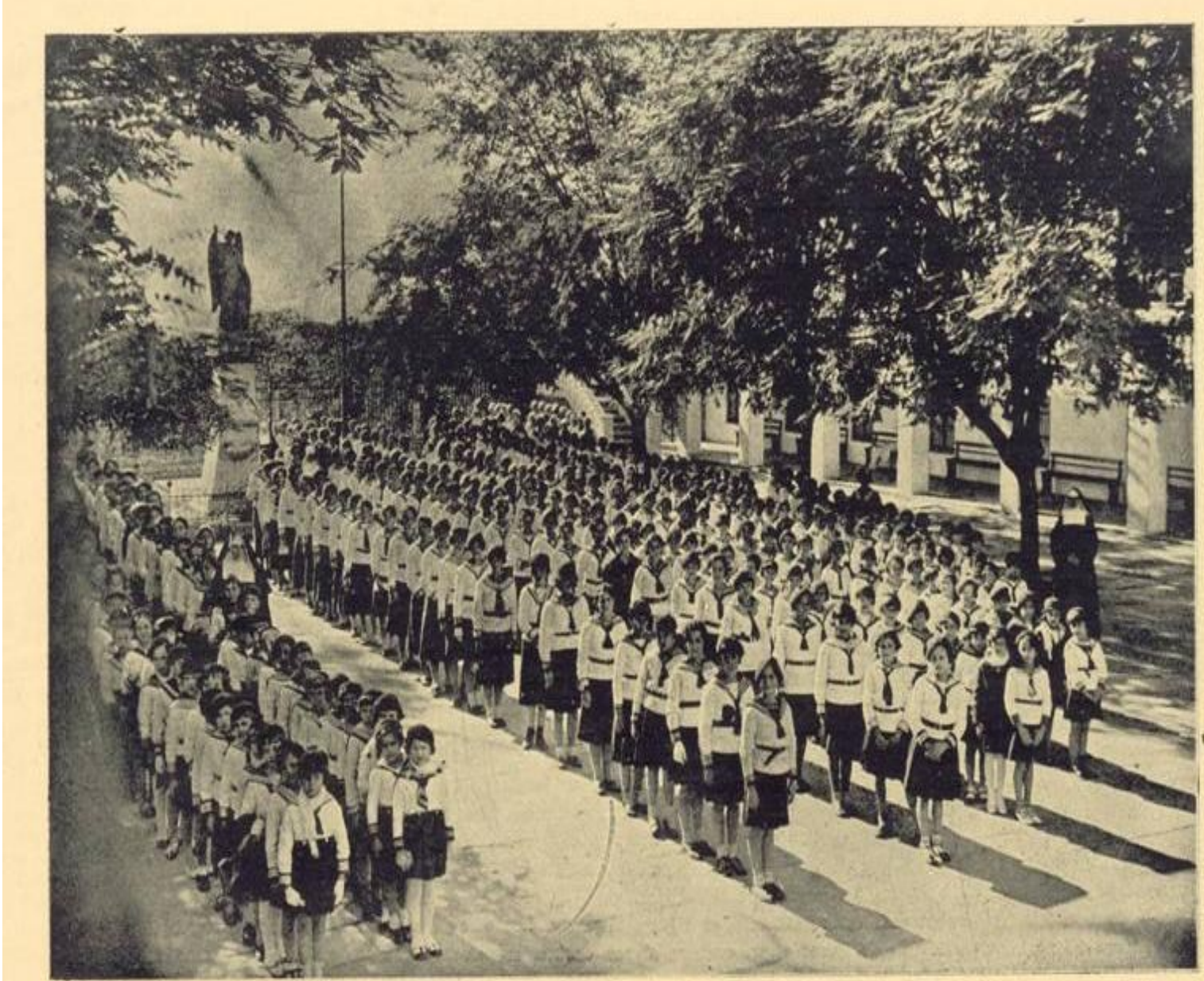

CORPO DE ALUNOS DO GINÁSIO BOM CONSELHO EM DIA DE DESFILE PATRIO

Fonte: Franco, A. et al. Porto Alegre: biografia duma cidade. Monumento do passado, documento do presente, guia do futuro. Porto Alegre: Tipografia do Centro, s.d.

Ressalta-se que para a construção de uma visualidade fotográfica os alunos uniformizados e dispostos em filas proporcionam a criação de um sentido de homogeneidade, pois o uniforme proporciona a repetição dos elementos visuais na presença de cada sujeito individualizado. Desse modo, a imagem fotográfica torna visível uma das tecnologias do poder levadas a efeito pela escola moderna, pois, conforme Inés Dussel, "los uniformes escolares son señales y práticas significantes que llevan consigo significados sobre identidad y diferencia, y que representam La disciplinación del cuerpo por parte de um poder que somete y subjetiva (produce subjetividades)" (Dussel, 2003, p. 208). 
Assim, é importante frisar que se nesse caso específico ${ }^{4}$ o uniforme produz efeitos visuais de homogeneidade, apenas a partir da fotografia é possível à História da Educação a aproximação desse sentido, pois o ato tornado passado é irrecuperável, assim como os traços da cultura material não permitem tal aproximação.

É interessante observar que esse corpo homogêneo e ordeiro de alunos é dado a ver fora do contexto escolar, inserido no espaço urbano. Uma única imagem interna de uma edificação escolar que apresenta sujeitos - duas freiras do Colégio Sevigné (fotografia 5) - acaba por representar o corpo de alunos ou alunas por sua ausência ou invisibilidade.

\section{Fotografia 5 -}

As arcadas do Colégio Sevigné, de onde a vista alcança até a outra margem do riacho e de onde se desfruta uma tranquila visão da cidade (legenda original).

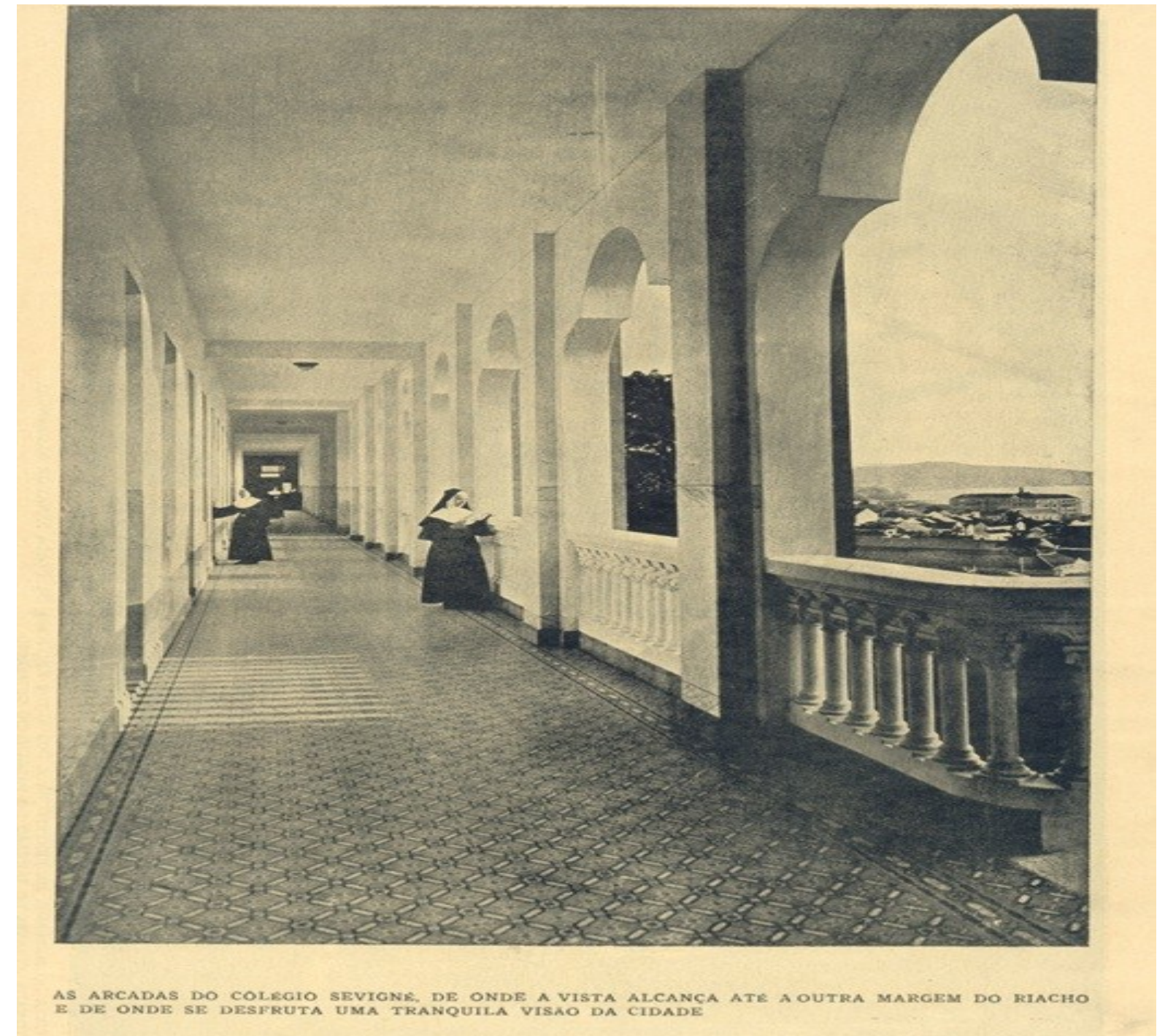

Fonte: Franco, A. et al. Porto Alegre: biografia duma cidade. Monumento do passado, documento do presente, guia do futuro. Porto Alegre: Tipografia do Centro, s.d.

${ }^{4}$ Inés Dussel (2003) traça uma história dos uniformes escolares no contexto da escolarização de massas, nos estados modernos, identificando a uniformização como técnica disciplinar eficiente que contempla múltiplos discursos que revestem os uniformes de significados distintos de acordo com os contextos históricos analisados.

Hist. Educ. [Online]

Porto Alegre

v. 19

ก. 47

Set./dez., 2015

p. $129-148$ 
Desse modo,

ver fotografias escolares como analisadores e, assim, repletas de informações, significados e tensões culturais, requer também que reconheçamos a presença da ambigüidade. A ambigüidade intrínseca do status das imagens, tanto como substância material, contendo a informação, quanto como representação icônica, direciona nosso olhar para a relação parece-ser que todas as imagens incorporam. (Fischman; Cruder, 2003, p. 47)

Nesta imagem operou-se uma trama entre visível e invisível (Meneses, 2005), na qual se enuncia uma imagem da escola ideal, cujos principais sujeitos, os estudantes, foram invisibilizados. A imagem fotográfica em questão, dessa forma, torna imperativo ao observador imaginar um extra-quadro, contido no interior das salas de aula, onde se encontrariam alunos e mestres, não tornado imagem pelo fotógrafo. Aqui, no espaço escolar, os alunos estão invisíveis. No álbum analisado, quando tornados visíveis, esses sujeitos são apresentados em atividade externa ao espaço escolar e devidamente organizados e submetidos à ordem da cidade. Cabe ainda ressaltar que a interpretação das imagens fotográficas aqui suscitada torna-se possível ao serem estabelecidas relações entre diferentes imagens dispostas no interior do álbum Biografia duma cidade, assim como o diálogo com outros corpus visuais em contexto permitem explorar essas confrontações.

Michel Foucault (1989), investigando a constituição da sociedade disciplinar - da qual a escola é uma de suas instituições basilares - afirma ser o corpo objeto e alvo do poder. Para exercer o controle, o corpo é concebido como unidade a ser esquadrinhada minuciosamente. Sobre ele exerce-se uma coerção constante moldando movimentos, gestos, tempos e ritmos a fim de assegurar a submissão de sua força e a aumentar a sua eficiência. A disciplina seria, segundo o autor, a sujeição de corpos dóceis ao controle sistemático. A disciplina assegura a distribuição dos indivíduos no espaço, determinando o lugar de cada um. As imagens de paradas e desfiles alocam no cenário urbano os alunos individualizados de forma ordeira e submissa. No contexto da construção de uma representação de cidade ordeira, essas imagens criam o sentido de controle sobre as massas populacionais, banindo a presença de aglomerações ou indivíduos descontrolados e não docilizados.

É importante ponderar, no entanto, que o exercício do poder disciplinar em Foucault, conforme Durval Albuquerque (2004) não é concebido como maquinaria sem saída, em que a capacidade de criação, invenção e imaginação da história está comprometida. Ao contrário, segundo o autor, para Foucault

pensar o poder como um elemento fundamental do jogo da história é tomálo como resultante sempre indefinida e indeterminada do embate das forças que compõem um dado campo social, é tomá-lo como sendo materializado em um conjunto de regras e de normas, que estão sempre sendo negociadas, jogadas. (Albuquerque, 2004, p. 90)

É flagrante as diferenças dessas imagens em relação, por exemplo, às imagens fotográficas criadas por Virgílio Calegari (Possamai, 2013) na segunda década do século 20 , nas quais a presença da multidão no espaço urbano poderia ser interpretada como 
sinônimo de modernidade. Vinte anos depois, certamente o crescimento populacional de Porto Alegre é considerado auspicioso, mas também é motivo de apreensão por parte das autoridades públicas, desejosas de ter o máximo de ordem e controle assegurados na cidade. Por outro lado, as imagens de paradas e desfiles levam ao foco da cena os escolares, criando a ideia de que o papel da educação é criar corpos dóceis para a sociedade, que mesmo fora do âmbito escolar, espraia-se organizadamente por outros espaços da cidade sem desintegrar-se e ameaçar a ordem social. Essa ordem é dada pela fila, onde cada indivíduo dispõe de uma posição, e pela marcha, que transforma a presença dos escolares em ato (fotografia 6). De modo contundente e inequívoco, todas as imagens de escolares presentes em Porto Alegre: biografia duma cidade os apresenta em filas, marchando nas paradas.

Fotografia 6 -

A juventude desfila, Ana avenida Borges de Medeiros (legenda original).

\section{A PARADA DA MOCIDADE E ATOS OFICIAIS}
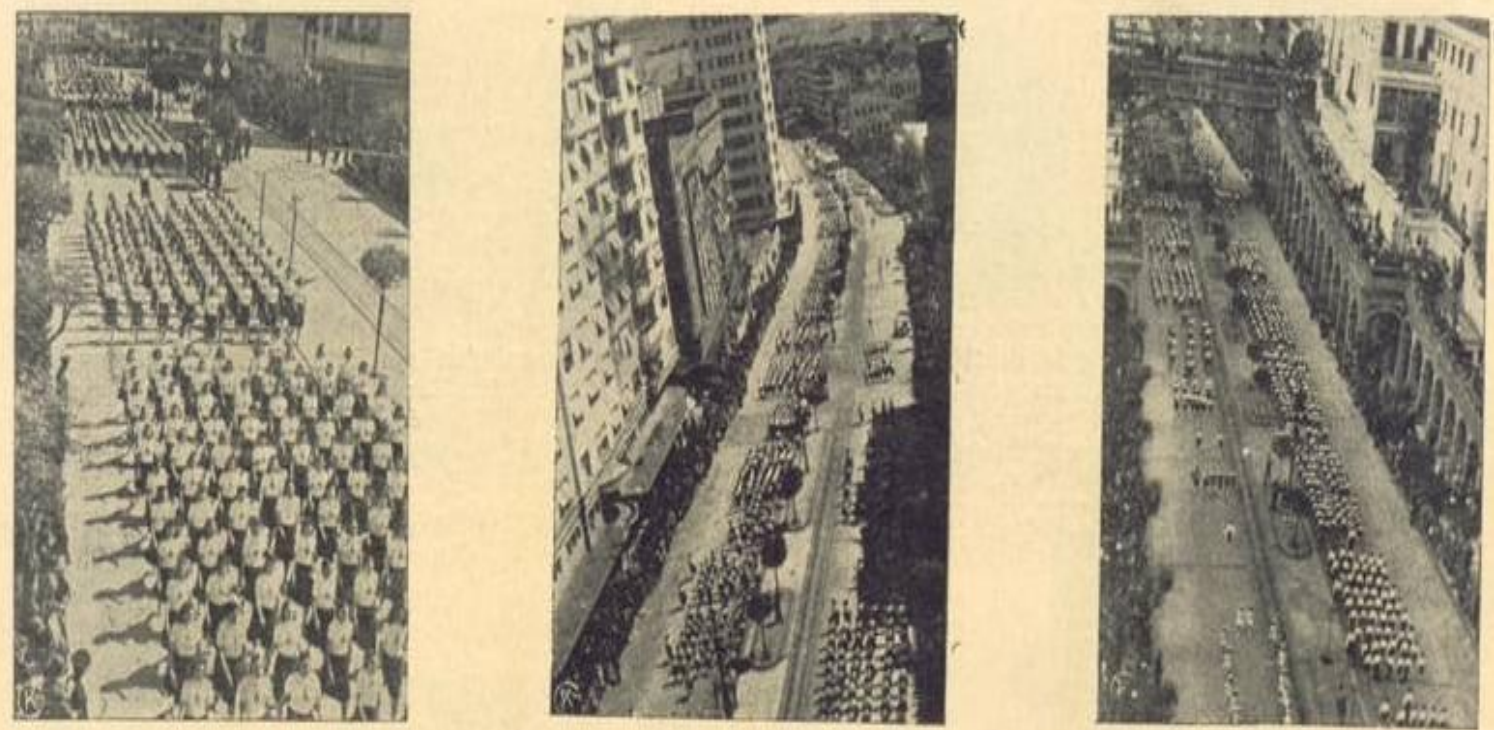

A JUVENTUDE DESFILA, NA AVENIDA BORGES DE MEDEIROS

Fonte: Franco, A. et al. Porto Alegre: biografia duma cidade. Monumento do passado, documento do presente, guia do futuro. Porto Alegre: Tipografia do Centro, s.d.

É importante mencionar a preocupação com o corpo físico como central no pensamento que embasou a configuração da escola moderna. Conforme Marcus Taborda de Oliveira (2006), "o corpo físico passava a ser talvez a principal possibilidade de reordenação do corpo político da sociedade, e a escola cumpriria um papel preponderante na sua realização" (p. 187). Dessa forma, a submissão dos corpos infantis pela escolarização faz parte de um processo mais amplo de construção de uma nova ordem urbano-industrial à qual corresponderia uma cultura específica, sendo a cultura escolar 
uma de suas dimensões. A fotografia, como engenho técnico surgido nesse contexto e capaz de criar imagens consideradas como duplicação da realidade, tornou-se um dos expedientes de exercício do olho do poder sobre os corpos dos indivíduos (Santos, 1996).

Dessa forma, as imagens fotográficas apontam para a inserção no contexto urbano de uma cultura escolar, marcada pela massificação, em contexto no qual era significativo o número de frequentadores das escolas. No início do século 20 o Estado do Rio Grande do Sul possuía 40 mil alunos; na década de 1920 esse número aumentara para 100 mil; em menos de uma década esse número dobrou para 200 mil, segundo estatísticas para o ano de 1927 (Bastos, 2005). Segundo dados apresentados no álbum, em 1937, o número de matrículas era de 298.118 alunos; em 1939 subira para 363.712 alunos, ultrapassando 400.000 alunos em 1940 (Franco, s.d., p. 320), sendo que nas paradas por ocasião da Semana da Pátria haviam desfilado 30 mil alunos.

Embora as estatísticas apresentadas em Biografia estejam sobrevalorizadas ${ }^{5}$, é possível imaginar que o contingente de corpos reunidos tornava imperativo o processo de disciplinamento como meio pelo qual a ordem seria estabelecida. Inseridos esses corpos no espaço urbano por meio dos desfiles, transfere-se essa organização para a cidade, construindo-se uma representação ideal da Porto Alegre ordeira. Certamente essa imagem estava muito distante da vida cotidiana de uma cidade que atingira 385 mil habitantes e cujo processo de verticalização na área central acompanhava o surgimento de áreas empobrecidas, como podem ser vistas em diversas imagens fotográficas do período e cuja complexidade criava novos problemas urbanos a serem equacionados.

Ademais, se a configuração disciplinar é a forma escolhida para tornar visível os escolares, por outro lado, sua presença na fotografia indica ser o desfile uma estratégia de lançá-los ao olhar da sociedade, constituindo-se como observatório desses indivíduos docilizados. O poder disciplinar torna obrigatória a visibilidade dos sujeitos submetidos, sendo a sua constante exposição ao olhar da sociedade que os mantém disciplinados. A fotografia, nesse sentido, constitui-se em veículo capaz de transpor esse jogo do olhar disciplinar, transferindo-o do contexto da cidade para a representação visual na publicação. Dessa forma, as imagens fotográficas de escolares em fila, movimentando-se de forma organizada cria uma visibilidade que se coaduna com o poder disciplinar exercido pelo olhar, potencializado pelo olhar fotográfico, instituidor de um ponto de vista a partir do qual a cena é organizada e hierarquizada em conformidade com o seu autor (Dubois,1992; Flusser, 2002). Ao sofrerem um segundo arranjo na edição do álbum, a expensas do produtor das imagens, as cenas são agrupadas e potencializadas no sentido desejado.

Assim, visível e invisível, propostos como modos a partir dos quais o poder constrói determinadas visualidades, no conjunto de imagens aqui analisadas, aponta menos para uma oposição entre esses dois termos. Em Porto Alegre: biografia duma cidade a visibilidade é imperativo a partir do qual atesta-se a presença dos sujeitos escolarizados, ou seja, docilizados pela cultura escolar. A partir das imagens são construídos sentidos de ordem escolar e ordem urbana. A fotografia, nesse sentido, por suas particularidades

\footnotetext{
${ }^{5}$ Os dados referentes à matrícula efetiva apresentados pela Diretoria de Estatísticas Educacionais registram para o ano de 1937, 267.339 alunos; para o ano de 1939, 301.158 alunos e para o ano de $1940,317.985$ alunos, conforme Bastos (2005, p. 65). 
formais de oferecer a criação de um ponto de vista que submete os sujeitos e motivos em foco ao olhar do fotógrafo, foi ao encontro dos modos de controle disciplinares da educação moderna, possibilitando a imaginação de uma visualidade escolar específica. Como visto, a grafia da educação no espaço escolar e no espaço urbano é feita a partir do exercício do olhar do poder possibilitado pela grafia da luz - a fotografia.

\section{Referências}

ALBUQUERQUE, Durval Muniz de. A história em jogo: a atuação de Michel Foucault no campo da historiografia. Anos 90, Porto Alegre: Ufrgs, v. 11, n. 19/20, 2004, p.79-100.

BARROS, Armando Martins de. Imagem, cultura, escola: os cartões postais e o ensino público no Distrito Federal da primeira república. REUNIÃO ANUAL DA ANPED, 17, 1994. Anais ... Caxambu: Anped, 1994, p. 203-212.

BASTOS, Maria Helena Camara. A revista do ensino no Rio Grande do Sul (1939-1942): o novo e o nacional em revista. Pelotas: Seiva, 2005.

BENCOSTTA, Marcus Levy Albino. Memória e cultura escolar: a imagem fotográfica no estudo da escola primária de Curitiba. História (São Paulo), v. 30, n. 1, 2011, p. 397-411.

BENCOSTTA, Marcus Levy Albino. Desfiles patrióticos: cultura cívica nos grupos escolares de Curitiba (1003-1971). CONGRESSO BRASILEIRO DE HISTÓRIA DA EDUCAÇÃO, 3, 2004. Anais ... Curitiba: PUCPR, 2004.

DUBOIS, Philippe. O acto fotográfico. Lisboa: Vega, 1992.

DUSSEL, Inés. Uniformes escolares y la disciplina de lãs apariencias: hacia uma historia de la regulación de los cuerpos en los sistemas educativos modernos. In: POPKEWITZ, Thomas S.; FRANKLIN, Barry M.; PEREYRA, Miguel A. (comp.). Historia cultural y educación: ensayos críticos sobre conocimiento y escolarización. Barcelona: Pomares, 2003, p. 15-58.

FARIA FILHO, Luciano Mendes de; VIDAL, Diana Gonçalves. Os tempos e os espaços escolares no processo de institucionalização da escola primária no Brasil. Revista Brasileira de Educação, n. 14, 2000, p. 19-34.

FELGUEIRAS, Margarida Louro. Materialidade da cultura escolar: a importância da museologia na conservação/comunicação da herança educativa. Pro-Posições, Campinas: Unicamp, v. 16, n. 1, 2005, p. 87-102.

FERREZ, Marc; FERREZ, Gilberto; SANTOS, Paulo F. O álbum da Avenida Central: um documento fotográfico da construção da Avenida Rio Branco, Rio de Janeiro, 1903-1906. Rio de Janeiro: João fortes engenharia/Ex-Libris, 1982.

FISCHMAN, Gustavo E.; CRUDER, Gabriela. Fotografias escolares como evento na pesquisa em educação. Educação e Realidade, Porto Alegre: Ufrgs, v. 28, n. 2, 2003, p. 39-53.

FOUCAULT, Michel. Vigiar e punir: história da violência nas prisões. Petrópolis: Vozes, 1989.

FLUSSER, Vilém. Filosofia da caixa preta: ensaios para uma futura filosofia da fotografia. Rio de Janeiro: Relume Dumará, 2002.

FRANCO, Álvaro et al. Porto Alegre: biografia duma cidade - monumento do passado, documento do presente, guia do futuro. Porto Alegre: Tipografia do Centro, s.d. 
FRIZOT, Michel. Fotografia: um destino cultural. In: SANTOS, Alexandre; CARVALHO, Ana Albani de. Imagens: arte e cultura. Porto Alegre: Ufrgs, 2012, p. 19-45.

GERTZ, René E. O Estado Novo no Rio Grande do Sul. Passo Fundo: UPF, 2005.

HERNANDEZ, Fernando. Cultura visual, mudança educativa e projeto de trabalho. Porto Alegre: Artmed, 2000.

KNAUSS, Paulo. O desafio de fazer história com imagens: arte e cultura visual. Artcultura, Uberlândia, v. 8, n. 12, 2006, p. 97-115.

KOSSOY, Boris. Realidades e ficções na trama fotográfica. São Paulo: Ateliê, 2002.

KREUTZ, Lucio. Escolas da imigração alemã no Rio Grande do Sul: perspectiva histórica. In: MAUCH, Cláudia, VASCONCELLOS, Naira. Os alemães no sul do Brasil: cultura, etnicidade, história. Canoas: Ulbra, 1994, p. 149-161.

JULIA, Dominique. A cultura escolar como objeto histórico. Revista Brasileira da Educação, n. 1, 2001, p. 9-43.

MACHADO, Arlindo. A ilusão especular: introdução à fotografia. São Paulo: Brasiliense, 1984.

MENESES, Ulpiano Toledo Bezerra de. Rumo a uma história visual. In: MARTINS, José de Souza; ECKERT, Cornelia; NOVAES, Sylvia (org.). O imaginário e o poético nas ciências sociais. Bauru: Edusc, 2005, p. 33-56.

MONDENARD, Anne de. A emergência de um novo olhar sobre a cidade: as fotografias urbanas de 1870 a 1918. Projeto História, São Paulo, n. 18, 1999.

MONTEIRO, Charles. Construindo a história da cidade através de imagens. In: PESAVENTO, Sandra Jatahy; SANTOS, Nádia Maria Weber; ROSSINI, Miriam de Souza. Narrativas, imagens e práticas sociais: percursos em história cultural. Porto Alegre: Asterisco, 2008, p. 148-171.

OLIVEIRA, Marcos A. Taborda de. Educando pelo corpo: saberes e práticas na instrução pública primária paranaense (finais do séc. 19, início do séc. 20). Educativa, Goiânia, v. 9 , n. 2, 2006, p. 185-199, 2006.

POSSAMAI, Zita Rosane. Nos bastidores do museu: patrimônio e passado da cidade de Porto Alegre. Porto Alegre: Est, 2001.

POSSAMAI, Zita Rosane. Ensaio de um olhar moderno: imagens fotográficas no álbum Porto Alegre de Virgílio Calegari. Revista Latino-Americana de História, v. 2, n. 7, 2013, p. 41-53.

POSSAMAI, Zita Rosane. A cultura fotográfica e a escola desejada. ENCONTRO NACIONAL DE ESTUDOS DA IMAGEM, 2, 2009. Anais ... Londrina: UEL, 2009.

SANTOS, Alexandre Ricardo dos. Corpo e controle: o olho do poder e o esquadrinhamento individual: uma leitura foucaultiana dos primórdios da fotografia. Porto Arte, v. 7, n. 13, 1996, p. 55-68.

SOUZA, Rosa Fátima de. Fotografias escolares: a leitura de imagens na história da escola primária. Educar em Revista, Curitiba: UFPR, n. 18, 2001, p. 75-101.

VIDAL, Diana; ABDALA, Rachel. A fotografia como fonte para a história da educação: questões teórico-metodológicas e de pesquisa. Educação, Santa Maria: UFSM, v. 30, n. 2, 2005, p. 177-194. 
VIÑAO, Antonio. Memória, patrimonio y educación. Educatio Siglo XXI, v. 28, n. 2, 2010, p. 17-42.

ZITA ROSANE POSSAMAI é professora adjunta no Curso de Museologia e no Programa de Pós-Graduação em Educação da Universidade Federal do Rio Grande do Sul, doutora em História pela mesma universidade.

Endereço: Rua Santa Cecília 1899/204 - 90420-041 - Porto Alegre - RS - Brasil.

E-mail: zitapossamai@gmail.com.

Recebido em 6 de abril de 2015.

Aceito em 25 de junho de 2015. 